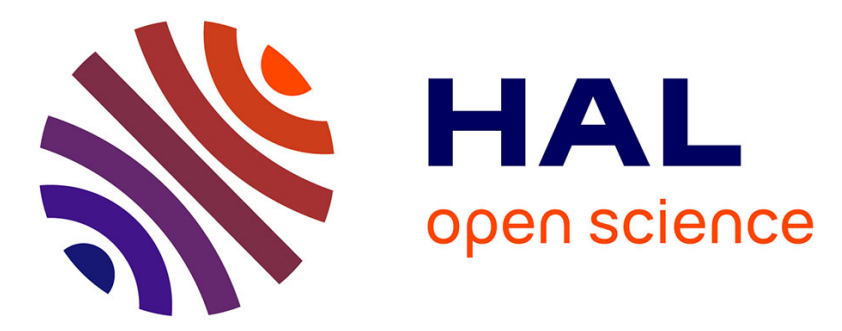

\title{
Human odontoblasts express functional thermo-sensitive TRP channels: Implications for dentin sensitivity
} Ikhlas El Karim, Gerard J Linden, Timothy M Curtis, Imad About, Mary K Mcgahon, Chris R Irwin, Fionnuala T Lundy

\section{- To cite this version:}

Ikhlas El Karim, Gerard J Linden, Timothy M Curtis, Imad About, Mary K Mcgahon, et al.. Human odontoblasts express functional thermo-sensitive TRP channels: Implications for dentin sensitivity. Pain, 2011, 152 (10), pp.2211-2223. 10.1016/j.pain.2010.10.016 . hal-03552154

\section{HAL Id: hal-03552154 \\ https://hal.science/hal-03552154}

Submitted on 2 Feb 2022

HAL is a multi-disciplinary open access archive for the deposit and dissemination of scientific research documents, whether they are published or not. The documents may come from teaching and research institutions in France or abroad, or from public or private research centers.
L'archive ouverte pluridisciplinaire HAL, est destinée au dépôt et à la diffusion de documents scientifiques de niveau recherche, publiés ou non, émanant des établissements d'enseignement et de recherche français ou étrangers, des laboratoires publics ou privés. 


\title{
Human odontoblasts express functional thermo-sensitive TRP channels: Implications for dentin sensitivity
}

\author{
Ikhlas A. El Karim ${ }^{a}$, Gerard J. Linden ${ }^{a}$, Timothy M. Curtis ${ }^{a}$, Imad About ${ }^{b}$, \\ Mary K. McGahon ${ }^{a}$, Chris R. Irwin ${ }^{a}$, Fionnuala T. Lundy ${ }^{\mathrm{a}, *}$ \\ a School of Medicine, Dentistry and Biomedical Sciences, Queen's University Belfast, Belfast, UK \\ ${ }^{\mathrm{b}}$ Laboratoire IMEB, Faculté d Odontologie, Université de la Méditerranée, Marseille, France
}

\section{A R T I C L E I N F O}

Keywords:

Dental pulp

Odontoblast

TRP channels

\begin{abstract}
A B S T R A C T
Odontoblasts form the outermost cellular layer of the dental pulp where they have been proposed to act as sensory receptor cells. Despite this suggestion, evidence supporting their direct role in mediating thermo-sensation and nociception is lacking. Transient receptor potential (TRP) ion channels directly mediate nociceptive functions, but their functional expression in human odontoblasts has yet to be elucidated. In the present study, we have examined the molecular and functional expression of thermo-sensitive TRP channels in cultured odontoblast-like cells and in native human odontoblasts obtained from healthy wisdom teeth. PCR and western blotting confirmed gene and protein expression of TRPV1, TRPA1 and TRPM8 channels. Immunohistochemistry revealed that these channels were localised to odontoblastlike cells as determined by double staining with dentin sialoprotein (DSP) antibody. In functional assays, agonists of TRPV1, TRPA1 and TRPM8 channels elicited $\left[\mathrm{Ca}^{2+}\right]_{i}$ transients that could be blocked by relevant antagonists. Application of hot and cold stimuli to the cells also evoked rises in $\left[\mathrm{Ca}^{2+}\right]_{i}$ which could be blocked by TRP-channel antagonists. Using a gene silencing approached we further confirmed a role for TRPA1 in mediating noxious cold responses in odontoblasts. We conclude that human odontoblasts express functional TRP channels that may play a crucial role in mediating thermal sensation in teeth.

(c) 2010 International Association for the Study of Pain. Published by Elsevier B.V. All rights reserved.
\end{abstract}

\section{Introduction}

Tooth (or dentin) hypersensitivity is an exaggerated response, characterised by short, sharp pain, arising from stimulation of exposed dentin [22]. Dentin hypersensitivity is a common finding in adult populations [20]. The underlying mechanisms of dentin sensitivity, and hypersensitivity, are not clearly understood and of the numerous advocated theories, the most widely accepted is the hydrodynamic theory [10]. This postulates that nociceptive responses may result from the activation of nerve endings resulting from an increase in intradentinal pressure due to fluid movements in dentinal tubules. However, based on this hydrodynamic concept it would be difficult to explain why there is so much variation in dentin sensitivity to different stimuli. It has been proposed that dentinal fluid flow may not be the only mechanism involved in thermal sensation in human teeth [27] and recent studies have demonstrated a lack of correlation between human pain sensation and dentinal fluid movement after cold stimulation [14].
Emerging evidence supports a role for odontoblasts as sensory cells that directly mediate tooth pain sensation [32]. Odontoblasts constitute the outermost cellular layer of the dental pulp and have cytoplasmic extensions which extend throughout the dentin. These odontoblast processes are housed within the dentinal tubules and lie in close proximity to sensory unmyelinated nerve fibres which extend from the dental pulp to the inner half of the dentin [11]. The idea that odontoblasts may sense external stimuli and transduce the signal to nearby nerves cells is supported by the close apposition of the odontoblasts to the dentinal nerve terminals $[11,34]$. In addition, odontoblasts are known to express several classes of ion channels which have been implicated in sensory reception and signal propagation, including L-type $\mathrm{Ca}^{2+}$ channels, mechanosensitive $\mathrm{K}^{+}$channels and voltage-gated $\mathrm{Na}^{+}$channels [3,33,4]. Although these findings support a role for odontoblasts in sensory transduction in teeth, the precise mechanisms through which these cells detect nociceptive stimuli has yet to be fully elucidated.

Thermal changes in the oral cavity are one of the most common triggers of dental pain [40]. Several members of the transient receptor potential (TRP) superfamily of ion channels are believed to play a critical role in sensory physiology, where they act as transducers for thermal, mechanical and chemical stimuli. Recent studies have shown that some members of the TRPV (vanilloid), 
Table 1

Primer sequence and cycling conditions used for gene expression experiments.

\begin{tabular}{|c|c|c|c|c|c|}
\hline Gene & Primer sequence $\left(3^{\prime} \rightarrow 5^{\prime}\right)$ & Annealing Temp. $\left({ }^{\circ} \mathrm{C}\right)$ & Cycles & Product size (bp) & Accession number \\
\hline DSPP & $\begin{array}{l}\text { Forward CCT AAA GAA AAT GAA GAT AAT T } \\
\text { Reverse TAG AAA AAC TCT TCC CTC CTA C }\end{array}$ & 51 & 36 & 293 & AJ002141 \\
\hline Nestin & $\begin{array}{l}\text { Forward GGC AGC GTT GGA ACA GAG GTT GGA } \\
\text { Reverse CTC TAA ACT GGA GTG GTC AGG GCT }\end{array}$ & 55 & 30 & 718 & AJ270321 \\
\hline TRPA1 & $\begin{array}{l}\text { Forward TGGTGCACAAATAGACCCAGT } \\
\text { Reverse TGGGCACCTTTAGAGAGTAGC }\end{array}$ & 60 & 35 & 318 & AY403101 \\
\hline TRPM8 & $\begin{array}{l}\text { Forward GATTTTCACCAATGACCGCCG } \\
\text { Reverse CCCCAGCAGCATTGATGTCG }\end{array}$ & 60 & 40 & 503 & AY328400 \\
\hline TRPV1 & $\begin{array}{l}\text { Forward CTCCTACAACAGCCTGTAC } \\
\text { Reverse AAGGCCTTCCTCATGCACT }\end{array}$ & 60 & 35 & 285 & NM_080706 \\
\hline
\end{tabular}

TRPM (melastatin) and the TRPA (ankyrin) subfamilies encode "thermo-TRPs" that respond to moderate or noxious changes in the external temperature. Examples include TRPV1 which responds to noxious heat, and TRPM 8 and TRPA1 which mediate cool and noxious cold sensations, respectively $[12,41,47,7]$. Heat-sensitive TRP channels have been demonstrated in rat trigeminal ganglion neurons [39] and TRPV1 is known to be expressed in rat odontoblasts $[37,45]$. No studies to date have addressed the expression and functional significance of thermo-sensitive TRP channels in human odontoblasts. In the present study, we show that human odontoblasts express TRPA1, TRPV1 and TRPM8 at both gene and protein level and confirm their functionality in response to chemical agonists and thermal stimuli.

\section{Materials and methods}

\subsection{Cell culture}

Immature permanent third molar teeth were obtained in accordance with French ethics legislation (informed patient consent and Institutional Review Board approval of the protocol used). Human odontoblast-like cells were derived from dental pulp as previously
DSPP \& nestin

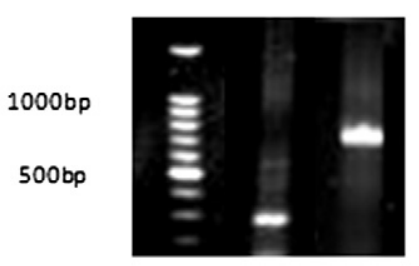

TRPV1

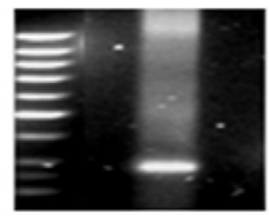

(A)

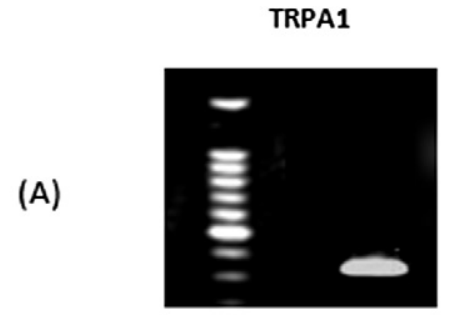

(B)
(C)

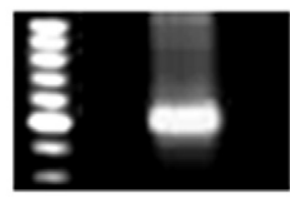

(D)
TRPA1

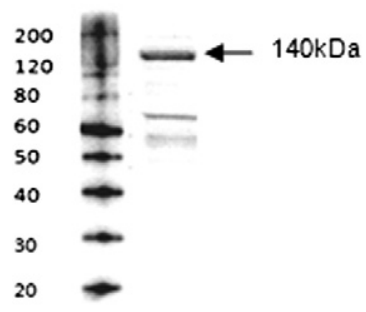

(E)
TRPV1

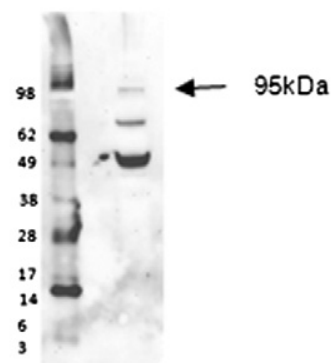

(F)
TRPM8

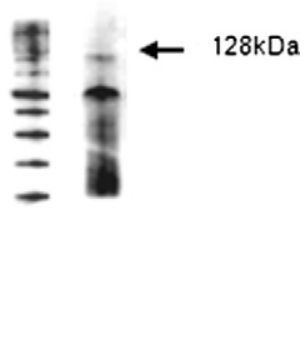

(G)

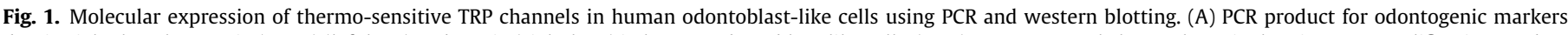

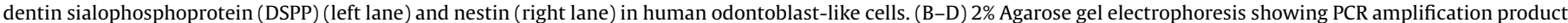

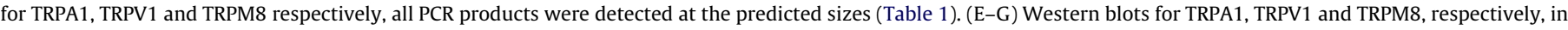
odontoblast-like cells detected at the predicted sizes. Representative results from at least three independent experiments are shown. 
described [1]. In brief, dental pulp cells derived from dental pulp explants were grown in minimal essential medium with L-glutamine supplemented with 10\% fetal bovine serum (FBS), $100 \mathrm{UI} / \mathrm{ml}$ penicillin and $100 \mu \mathrm{g} / \mathrm{ml}$ streptomycin. To differentiate pulp cells to odontoblasts the media were supplemented with $2 \mathrm{mM} \beta$-glycerophosphate. The odontoblastic phenotype of the cells was confirmed by the expression of the odontoblast markers dentin sialophosphoprotein (DSPP) and nestin. Cells in passage 4-6 were used in all subsequent experiments.

\subsection{Dental pulp slice preparation}

Dental pulp slices were prepared from healthy molar teeth obtained with the approval of the Office for Research Ethics Committees (Northern Ireland). Immediately after extraction, teeth were placed on ice cold Hanks solution and all gingival and periodontal tissues were removed with scalpel blades. Teeth were then clamped to the specimen chuck of an ISOMET Low Speed Saw (Buehler, Lake Bluff, IL), and sectioned transversely through the pulp, at a speed of 100 RPM, into $500 \mu \mathrm{m}$ thick slices. During sectioning, the tooth/blade interface was continually bathed in cold Hanks solution. Slices were collected immediately after sectioning and washed with Hanks solution prior to incubation in a solution containing $2 \mathrm{mg} / \mathrm{ml}$ collagenase Type 1 A (Sigma, UK) for $30 \mathrm{~min}$ at $37^{\circ} \mathrm{C}$. Following incubation, slices containing both dentin and pulp tissue were washed in Hanks solution and placed in glass dishes pre-coated with poly D-lysine and maintained in minimal essential medium with L-glutamine, supplemented with 10\% FBS, $100 \mathrm{UI} / \mathrm{ml}$ penicillin and $100 \mu \mathrm{g} / \mathrm{ml}$ streptomycin in a humidified atmosphere of $5 \% \mathrm{CO}_{2}$ at $37^{\circ} \mathrm{C}$.

\subsection{RNA extraction, $C D N A$ synthesis, and reverse transcriptase-PCR}

For RNA extraction cells were grown to $70 \%$ confluence in T75 flasks in minimal essential medium with L-glutamine supplemented with $10 \%$ fetal bovine serum (FBS), $100 \mathrm{UI} / \mathrm{ml}$ penicillin, $100 \mu \mathrm{g} / \mathrm{ml}$ streptomycin and $2 \mathrm{mM} \beta$-glycerophosphate. Total RNA from cells grown in culture was prepared using the RNeasy MiniKit (Qiagen) according to the protocol provided by the manufacturer. cDNA was synthesized from $1 \mu \mathrm{g}$ of extracted RNA with the Superscript ${ }^{\mathrm{TM}}$ First Strand Synthesis System (Invitrogen, Paisley, UK) and an oligo dT primer mix, according to the manufacturer's guidelines. For conventional RT-PCR sense and antisense PCR primers specific to human TRPA1, TRPV1 and TRPM8 and the
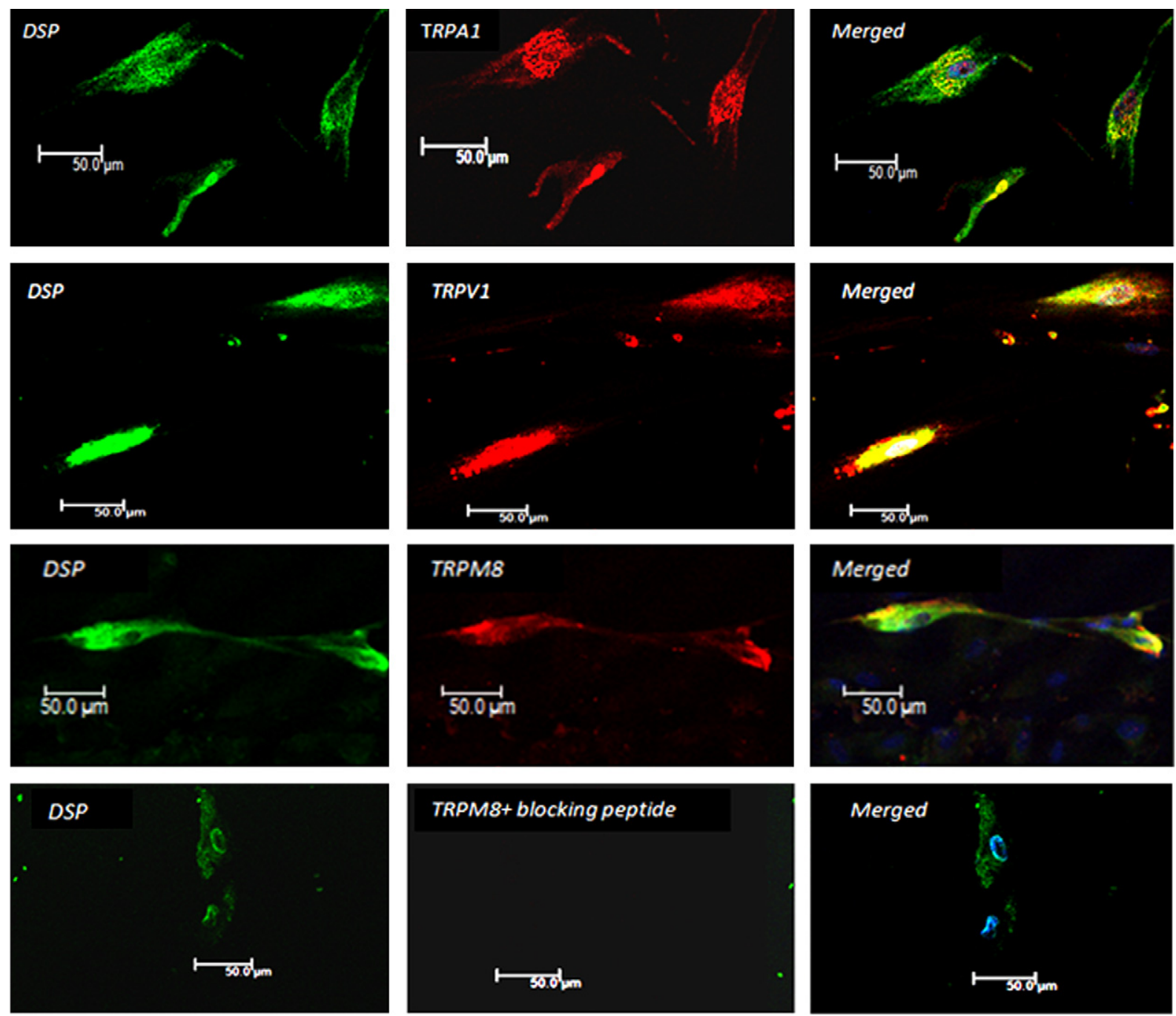

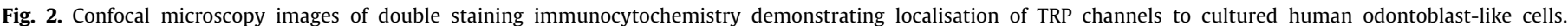

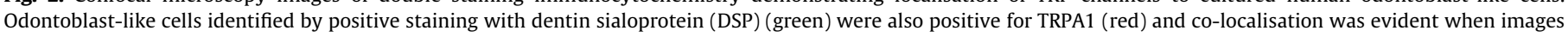

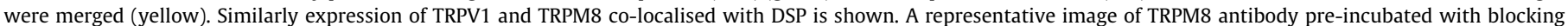
peptide showed no TRPM8. Cells were counterstained with DAPI for nuclear enhancement (blue). 
odontogenic markers nestin and DSPP were used (Table 1). PCR reactions were carried out using Platinum Taq DNA polymerase (Invitrogen) and reaction conditions as listed in Table 1. PCR products were analyzed by electrophoresis in $2 \%$ agarose gel and visualized by Ethidium Bromide staining. Parallel reactions were run for each RNA sample in the absence of reverse transcriptase to confirm that there was no genomic DNA contamination.

\subsection{Western blotting}

Cultured cells were lysed for 30 min on ice with $10 \mathrm{mM}$ Tris-HCL buffer ( $\mathrm{pH}$ 7.4) containing 1\% SDS and 'Complete' protease inhibitor cocktail (Roche, UK). Total protein in the cell lysate was determined using the bicinchoninic acid (BCA) protein assay and equal amounts of protein $(27 \mu \mathrm{g})$ were fractioned by SDS-polyacrylamide gel electrophoresis and blotted onto nitrocellulose. The blots were blocked in $5 \%$ non fat milk for $1 \mathrm{~h}$ prior to probing with rabbit polyclonal primary antibody to TRPA1 (ab31486; Abcam, UK), or TRPM8 (ab3243; Abcam, UK), or mouse monoclonal antibody to TRPV1 (H00007442M01; Abnova, USA) at 1:500 dilution overnight. Detection of the bound primary antibody was achieved using appropriate anti-species antibody conjugates (Dako, Denmark) and chemiluminescent substrates. All western blotting and PCR images were obtained using a Syngene $G$ box imaging system.

\subsection{Immunohistochemistry}

For double staining immunohistochemistry, cells were grown on cover slips, acetone-fixed and processed for indirect immuno- histochemistry using primary rabbit polyclonal antibodies against human TRPA1(ab68846; Abcam, UK), TRPV1 (ab63083; Abcam, UK) and TRPM8 (ACC-049; Alomone Labs, Jerusalem) and mouse monoclonal anti-human dentin sialoprotein (DSP) antibody (Sc73632; Santa Cruz, USA). Appropriate anti-species Alex Fluor 488 secondary antibody conjugates and Alexa Fluor 594 (Invitrogen, UK) were used for secondary detection. Briefly, specimens were incubated with primary rabbit antisera diluted 1:200 overnight at room temperature and then washed extensively with PBS before they were incubated overnight with DSP antibody (1:200). Following washing with PBS a 1:500 dilution of secondary antibody was then applied for $45 \mathrm{~min}$ at $37^{\circ} \mathrm{C}$. Tissue sections were washed again before mounting in VectaShield with DAPI $\left(4^{\prime}, 6\right.$ diamidino2-phenylindole) (Vector Lab., Burlingame, CA) to counterstain the nuclei. Control sections were incubated with non-immune serum in place of primary antibody. As additional controls, antibodies were pre-incubated with blocking peptides for $30 \mathrm{~min}$ prior to staining as described above.

For immunohistochemical localisation of TRPA1, TRPV1 and TRPM8 in human pulp tissue, healthy third molar teeth were fixed in a $4 \%$ formol solution and demineralised in a solution of $3.4 \%$ sodium formiate in $17 \%$ formic acid until fully decalcified for histological treatment. Samples were routinely processed through a series of graded alcohols and xylene, and finally embedded in paraffin wax. Rehydrated paraffin embedded sections $(7 \mu \mathrm{m})$ from human third molars were incubated with rabbit and mouse monoclonal antibody against TRPV1 (H00007442-M01; Abnova, USA) at 1:200 dilution and anti-human TRPA1 antibody (ab31486; Abcam, UK) or TRPM8 antibody (ACC-049; Alomone

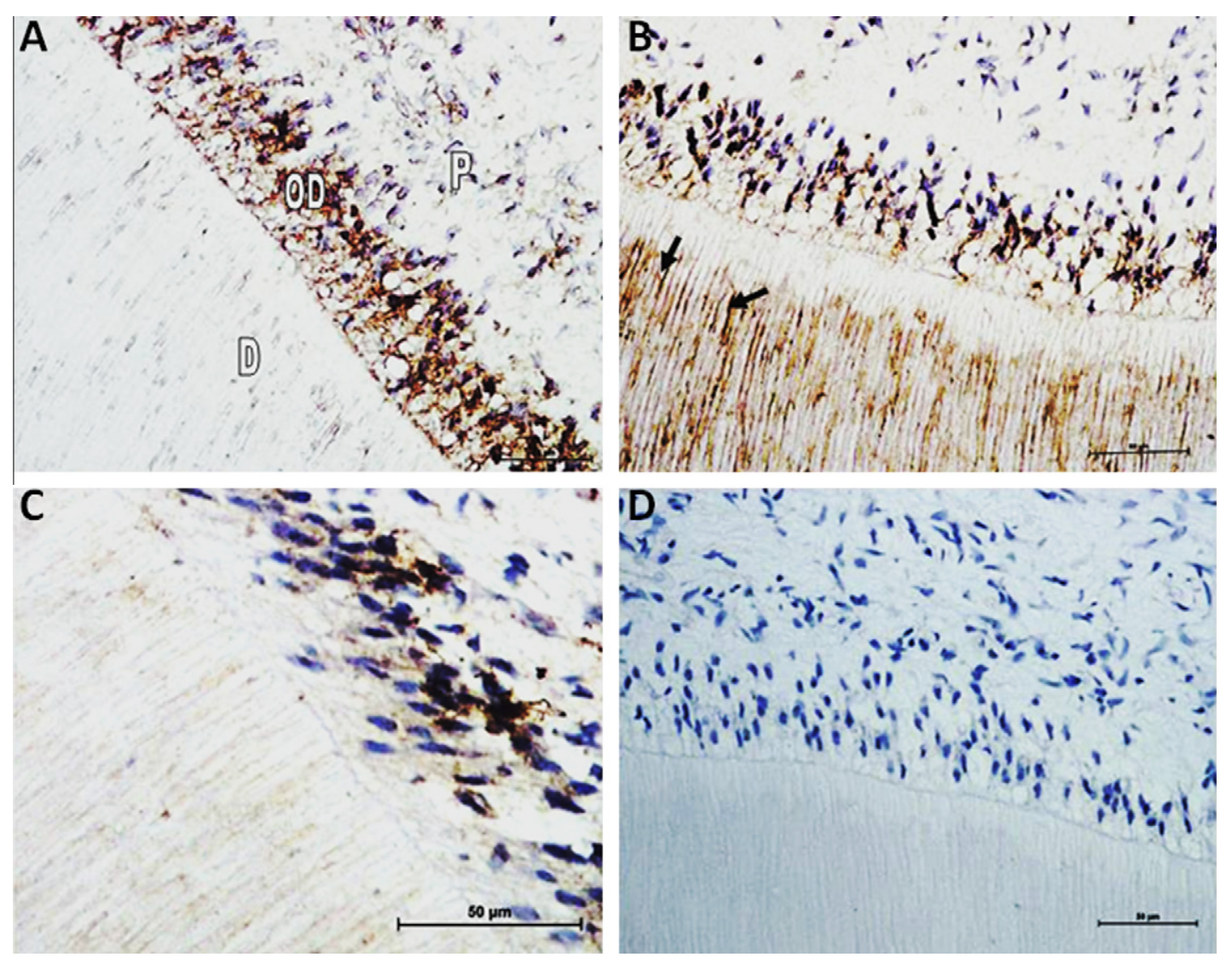

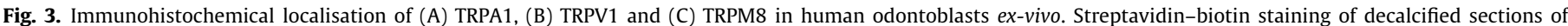

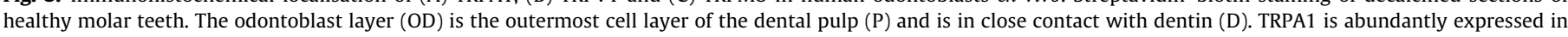

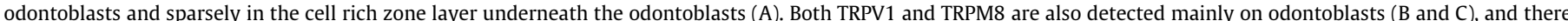

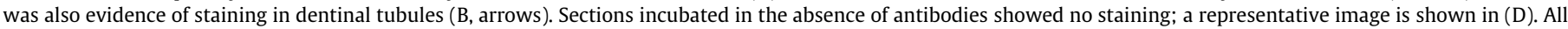
sections were counterstained with $\mathrm{H} \& \mathrm{E}$. Scale bar $=50 \mu \mathrm{m}$. 
Labs, Jerusalem) at 1:100 dilution overnight at $4^{\circ} \mathrm{C}$. Staining was revealed using the labelled streptavidin-biotin method (LSAB) (DakoCytomation, USA) according to the manufacturer's instructions.

Fluorescence immunohistochemistry images were obtained using a Leica TCS SP5 confocal microscope and light microscopy images were visualised using a Leica DMLB microscope.

\section{6. $\left[\mathrm{Ca}^{2+}\right]_{i}$ measurements}

$\left[\mathrm{Ca}^{2+}\right]_{\mathrm{i}}$ was estimated fluorometrically in both cultured and native odontoblasts, still embedded within dental pulp slice preparations, loaded with the intracellular $\mathrm{Ca}^{2+}$ probe fura-2AM. Cultured cells were grown on glass coverslips overnight in minimal essential medium with L-glutamine supplemented with $10 \%$ fetal bovine serum (FBS), $100 \mathrm{UI} / \mathrm{ml}$ penicillin and $100 \mu \mathrm{g} / \mathrm{ml}$ streptomycin prior to incubation in the dark with fura-2AM $(5 \mu \mathrm{M})$ for $1 \mathrm{~h}$ at $37^{\circ} \mathrm{C}$. Similarly dental pulp slice preparations were loaded with fura-2AM $(20 \mu \mathrm{M})$ for $1 \mathrm{~h}$ at $37^{\circ} \mathrm{C}$.

The coverslips bearing the adherent cells or dental pulp slice preparations were then placed in a recording chamber mounted on the stage of an inverted microscope (Nikon Eclipse TE2000) and superfused with Hank's solution at $37^{\circ} \mathrm{C}$. Only cells on the rim of the dental pulp corresponding to the anatomical location of native odontoblasts were used for recording from pulp slice preparations. The temperature of the chamber was controlled with an inbuilt Peltier device (PTC-10; ALA Scientific). Alternating excitation wavelengths of 340 and $380 \mathrm{~nm}$ light were delivered from a dual monochromator ( $5 \mathrm{~nm}$ bandwidth) using a light chopper (Cairn Research Ltd., Faversham, UK). Emitted fluorescence was measured from the side port of the microscope via an adjustable rectangular window, a filter $(510 \mathrm{~nm})$ and a photon counting photomultiplier tube (PMT) in the light path. Fluorescence

\section{(A)}
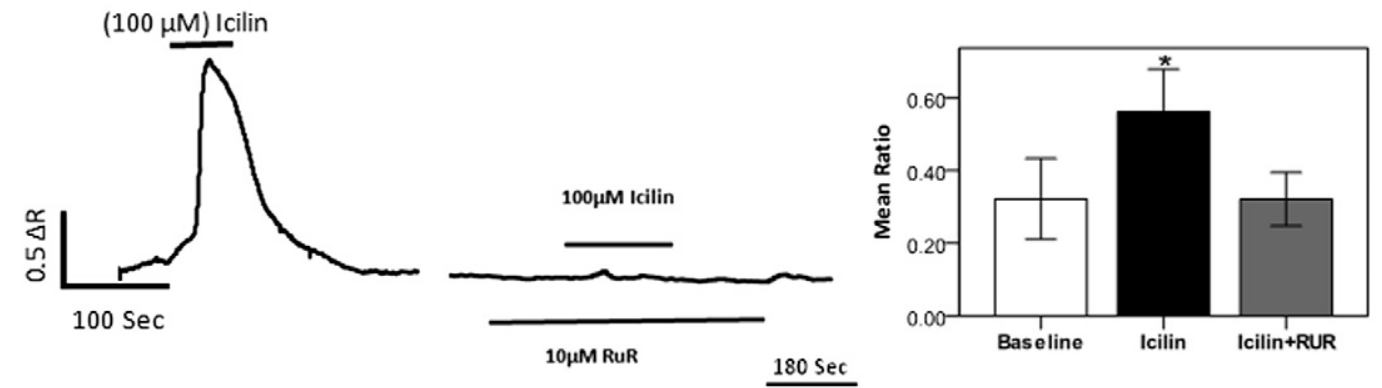

(B)
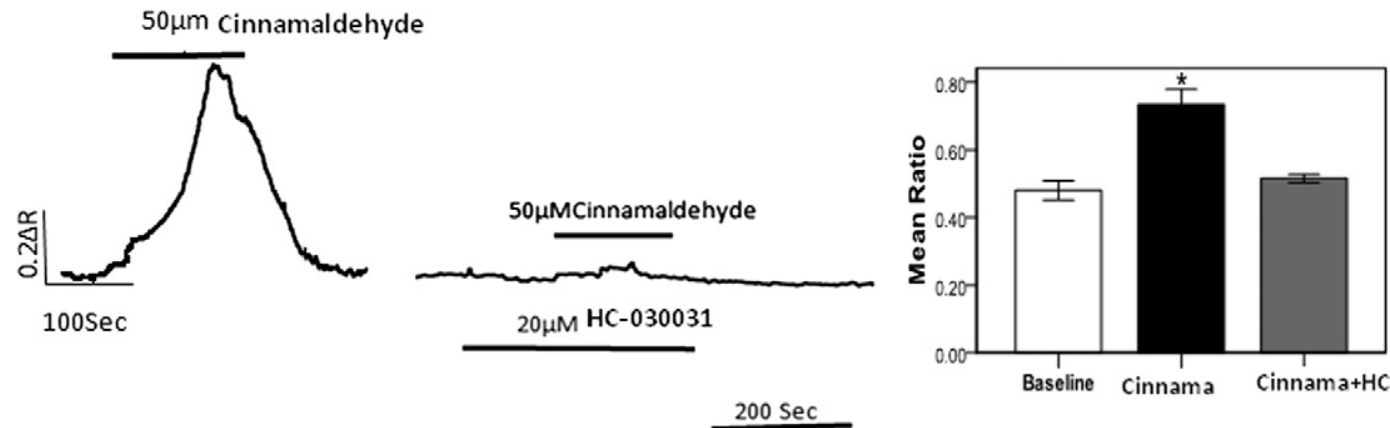

(c)
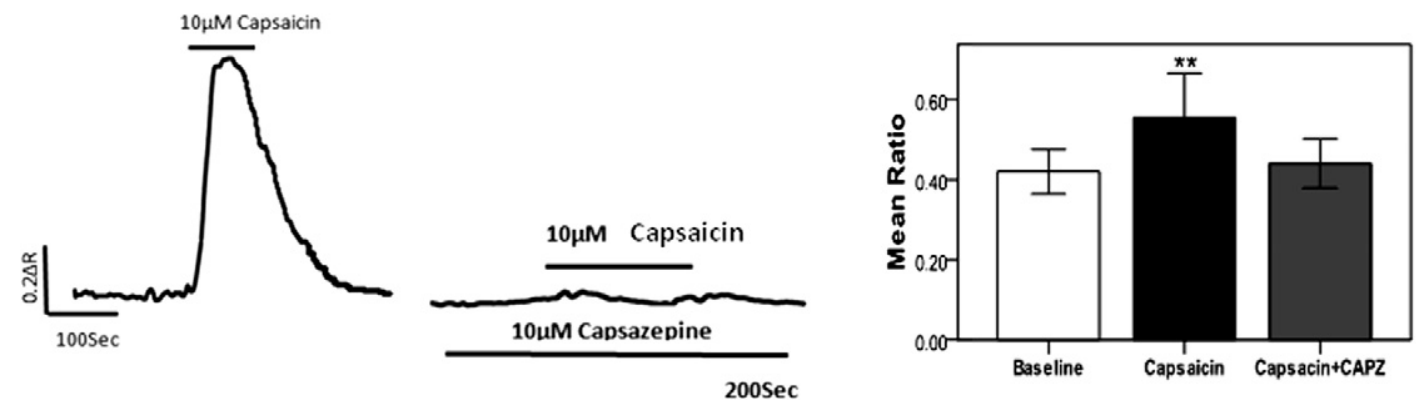

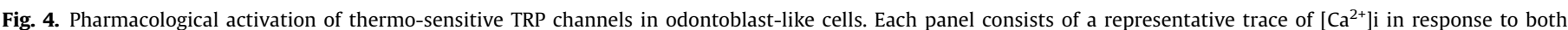

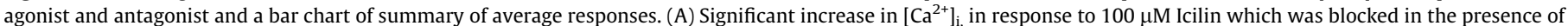

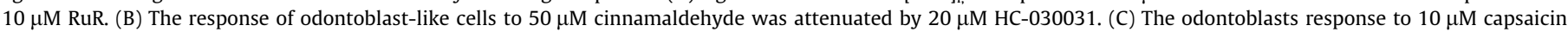

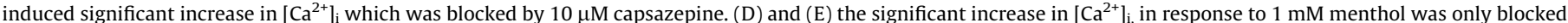

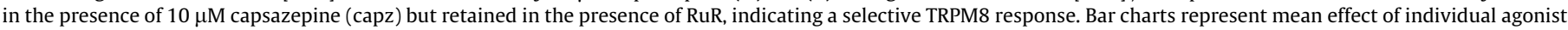
compared to baseline and antagonists, error bars indicate SEM, ANOVA, ${ }^{* *} p \leqslant 0.01 ;{ }^{*} p \leqslant 0.05$. 


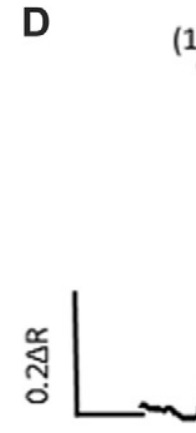

$100 \mathrm{Sec}$

$\mathbf{E}$
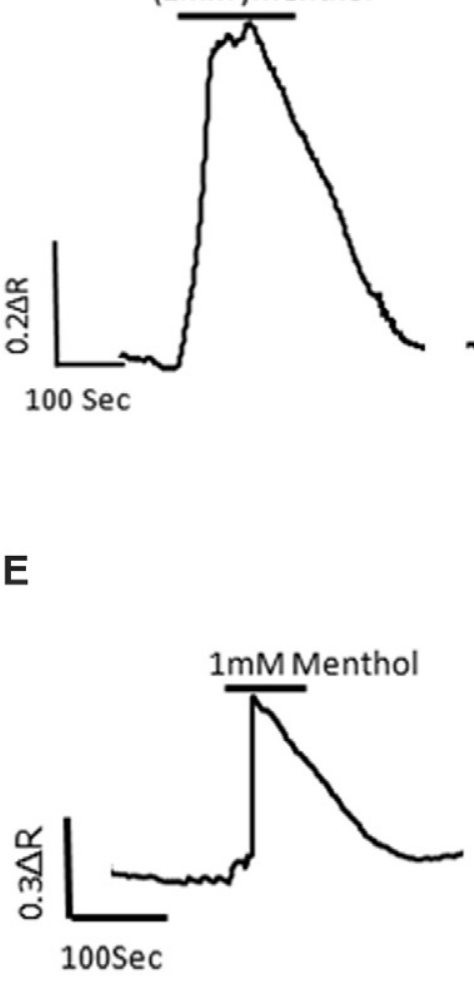

E

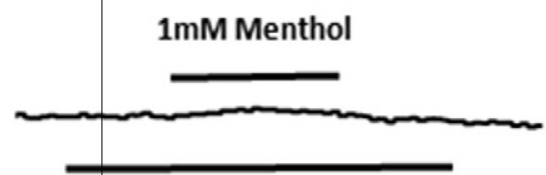

$10 \mu \mathrm{M}$ capsazepine

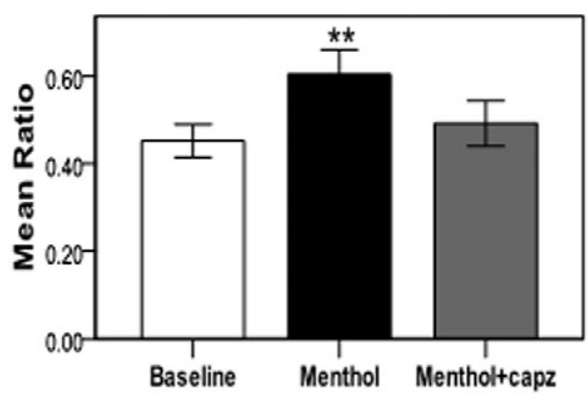

250 Sec

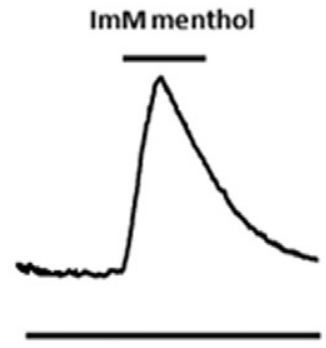

$10 \mu \mathrm{M}$ RuR

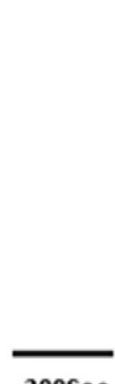

$300 \mathrm{Sec}$

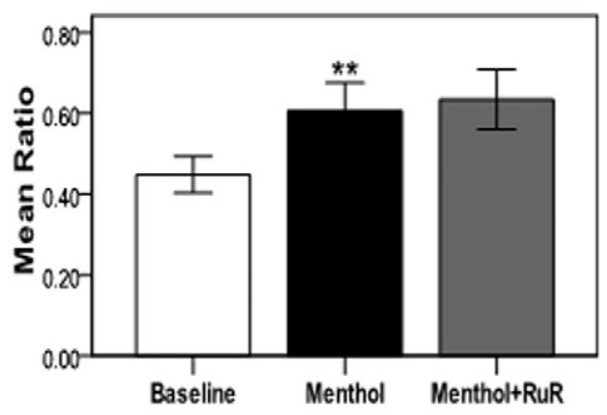

Fig. 4 (continued)

equipment was controlled by Acquisition Engine (Cairn) software (V1.1.5) which was also used for analysis of the fluorescence data. At the end of each experiment, background fluorescence was quantified by incubation of the cells with $5 \mathrm{mM} \mathrm{Mn}^{2+}$ in $\mathrm{Ca}^{2+}$-free solution. Changes in the ratio of the background-corrected fluorescence emitted at each excitation wavelength $(R=F 340 / F 380)$ was used as a measure of changes in the cytoplasmic $\mathrm{Ca}^{2+}$ concentration [21]. A positive $\mathrm{Ca}^{2+}$ response was defined as a change in the F340/F380 ratio >4 standard deviations above the background noise.

Cells were stimulated with the agonists capsaicin, menthol, cinnamaldehyde and icilin. Thermal stimuli were induced by increasing or decreasing temperature in the recording chamber at a rate of $0.13^{\circ} \mathrm{C} / \mathrm{s}$ using an inbuilt Peltier device (PTC-10; ALA Scientific). The TRP antagonist ruthenium red (RuR), the selective TRPV1 antagonist capsazepine (capz) and TRPA1 selective antagonist (HC-030031) were used to block the corresponding agonist and thermal responses.

\subsection{Small interference RNA (siRNA)}

Gene knockdown of human TRPA1 was performed by using HP Genome Wide siRNA (Qiagen UK). For siRNA transfection cells were grown in six-well plates to $30-50 \%$ confluence in minimal essential medium with L-glutamine supplemented with $10 \%$ fetal bovine serum (FBS), $100 \mathrm{UI} / \mathrm{ml}$ penicillin and $100 \mu \mathrm{g} / \mathrm{ml}$ streptomycin. $6 \mu$ TRPA1 siRNA was incubated with $14 \mu \mathrm{l}$ transfection reagent (Interferin ${ }^{\mathrm{TM}}$, Autogen Bioclear, UK) in $180 \mu \mathrm{l}$ serum free media for $15 \mathrm{~min}$ at room temperature to allow for formation of transfection complexes. The mixture was then added to each of the culture wells containing $2 \mathrm{ml}$ of minimal essential medium with L-glutamine supplemented with $10 \%$ fetal bovine serum and the cells incubated for $72 \mathrm{~h}$ (final siRNA concentration, $50 \mathrm{nM}$ ).
Western blot analysis was performed to confirm knockdown of TRPA1 protein expression. All experimental procedures were performed $24 \mathrm{~h}$ following the $72 \mathrm{~h}$ transfection period.

\subsection{Drugs and solutions}

Capsaicin, menthol, icilin, cinnamaldehyde, capsazepine, ruthenium red and $\beta$-glycerophosphate were obtained from Sigma UK, TRPA1 selective antagonist (HC-030031) from Tocris, UK, and fura-2AM from Enzo Life Sciences, UK. The physiological solution used contained $140 \mathrm{mM} \mathrm{NaCl}, 5 \mathrm{mM} \mathrm{KCl}, 5 \mathrm{mM}$ D-glucose, $1.3 \mathrm{mM} \mathrm{MgCl}_{2}, 2 \mathrm{mM} \mathrm{CaCl}_{2}, 10 \mathrm{mM}$ HEPES (free acid), pH 7.4.

Agonists and antagonists were used at concentrations previously described as follows; $100 \mu \mathrm{M}$ icilin [47,18], $50 \mu \mathrm{M}$ cinnamaldehyde [7,19] $20 \mu \mathrm{M}$ HC-030031 [19], $10 \mu \mathrm{M}$ capsaicin [45], $10 \mu \mathrm{M}$ capsazepine [12], $10 \mu \mathrm{M}$ RuR [12] and $1 \mathrm{mM}$ menthol [39].

\subsection{Data analysis}

Data are presented as means \pm SEM. For statistical analysis paired and unpaired Student $t$-tests or one way analysis of variance (ANOVA) were used with $p \leqslant 0.05$ considered statistically significant.

\section{Results}

\subsection{Molecular identification of thermo-sensitive TRP channels in human odontoblasts}

The odontoblastic phenotype in cultured cells was confirmed by expression of the odontoblast markers DSPP and nestin (Fig. 1A). Gene and protein expression of TRPA1, TRPV1 and TRPM8 in 


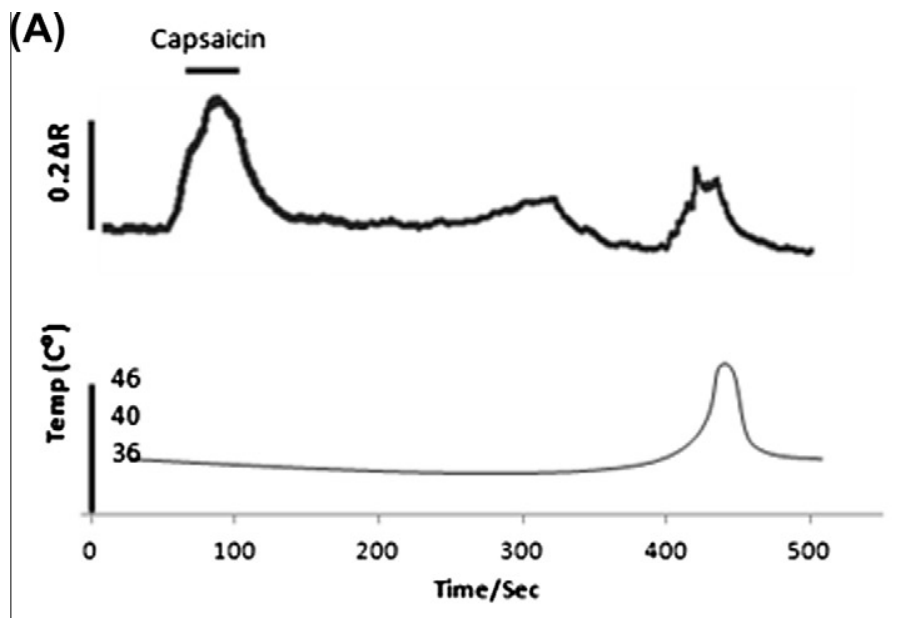

(B)

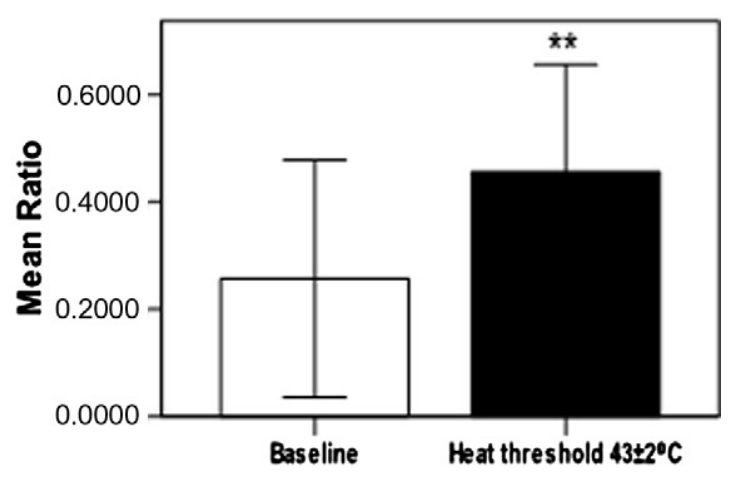

(C)
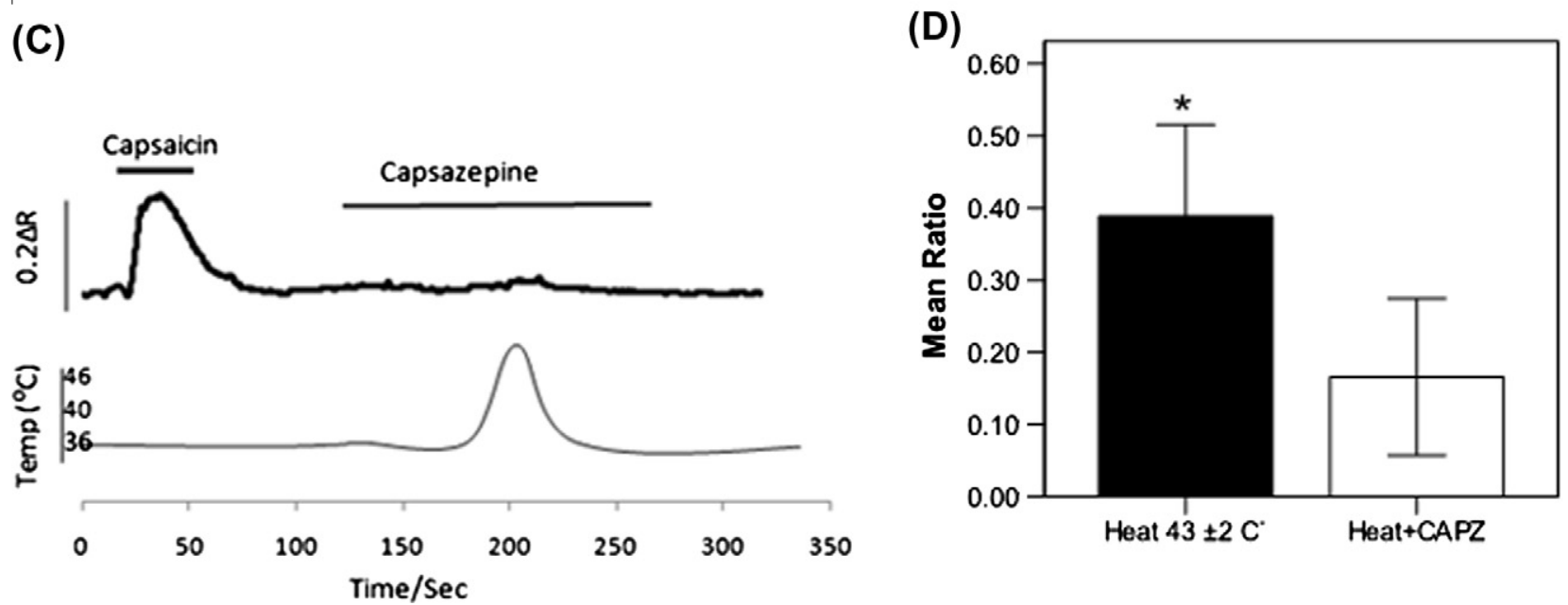

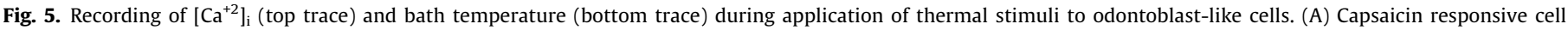

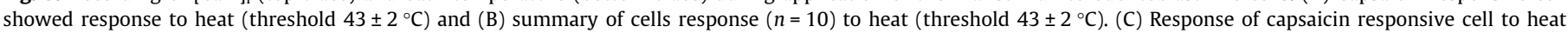

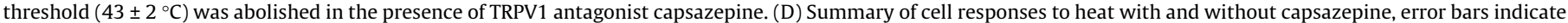
SEM, paired Student $t$ test ${ }^{* *} p \leqslant 0.01$, unpaired Student $t$ test ${ }^{*} p \leqslant 0.05$.

human odontoblast-like cells was demonstrated with PCR and western blotting. Electrophoresis of PCR products revealed strong intensity bands corresponding to predicted sizes of TRPA1, (Fig. 1B), TRPV1 (Fig. 1C) and TRPM8 (Fig. 1D). TRPA1, TRPV1 and TRPM8 proteins were detected at their expected molecular masses of $140 \mathrm{kDa}, 95 \mathrm{kDa}$, and $128 \mathrm{kDa}$, respectively (Fig. 1E-G).

Double staining immunohistochemistry revealed localisation of TRPA1, TRPV1, and TRPM8 to cultured odontoblast-like cells (Fig. 2). Identification of an odontoblast phenotype was determined by positive staining with DSP antibody. Co-localisation of TRP channels to these cells was evident when the confocal images were merged.

Furthermore TRPA1, TRPV1 and TRPM8 were also detected in native odontoblasts from healthy wisdom teeth. TRPA1 was abundantly expressed in odontoblasts and more sparsely expressed in some of the cells in the cell rich zone (Fig. 3A). Similarly TRPV1and TRPM8 were expressed mostly by odontoblasts (Fig. 3B and C), with staining also evident in the dentinal tubules (Fig. 3B).

\subsection{Functional expression of thermo-sensitive TRP channels in human odontoblasts}

\subsubsection{TRP ligands induce changes in $\left[\mathrm{Ca}^{2+}\right]_{i}$ in odontoblast-like cells}

The functional expression of TRPA1, TRPM8 and TRPV1 was initially investigated using $\mathrm{Ca}^{2+}$ microfluorimetry in cultured cells by measuring global changes in $\left[\mathrm{Ca}^{2+}\right]_{\mathrm{i}}$. In a control experiment to study the temporal profile of odontoblast responses to TRP ligands we found that odontoblasts respond to TRP ligands, icilin, capsaicin and menthol and that some of the cells respond to multiple agonists (Supplementary Fig. 1).

TRPA1 is a polymodal channel that is activated by a number of chemical agonists including icilin and cinnamaldehyde [47,7]. In this study $100 \mu \mathrm{M}$ icilin and $50 \mu \mathrm{M}$ cinnamaldehyde produced significant increase in $\left[\mathrm{Ca}^{2+}\right]_{\mathrm{i}}$, which was attenuated in the presence of RuR $(p<0.01, n=22)$ and the TRPA1 antagonist HC-030031 $(p=0.03, n=14$, Fig. 4 A and B).

Capsaicin is a specific TRPV1 agonist [12] and at $10 \mu \mathrm{M}$ concentration it produced a significant change in $\left[\mathrm{Ca}^{2+}\right]_{i}$ that was blocked by the selective TRPV1 antagonist capsazepine ( $p \leqslant 0.001, n=27$, Fig. 4C). Menthol is classical agonist for TRPM8 but can also activate TRPA1 $[41,25]$. At $1 \mathrm{mM}$ concentration menthol produced a significant increase in $\left[\mathrm{Ca}^{2+}\right]_{\mathrm{i}}$ and to differentiate TRPM8 from TRPA1 responding cells we studied the effects of antagonists on the menthol responses. We found that in some of the cells the menthol response was blocked by the TRPM8 antagonist capsazepine [28,51] and retained in the presence of $\operatorname{RuR}(p=0.001, n=8$, Fig. 4D and E) indicating functional expression of TRPM8 in these cells, while in other cells the menthol responses were not blocked in the presence of capsazepine (data not shown). 


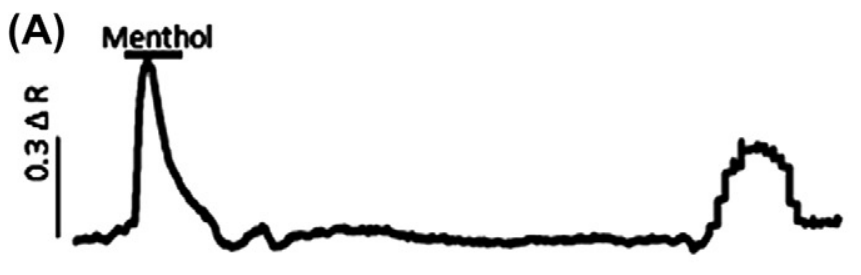

(B)
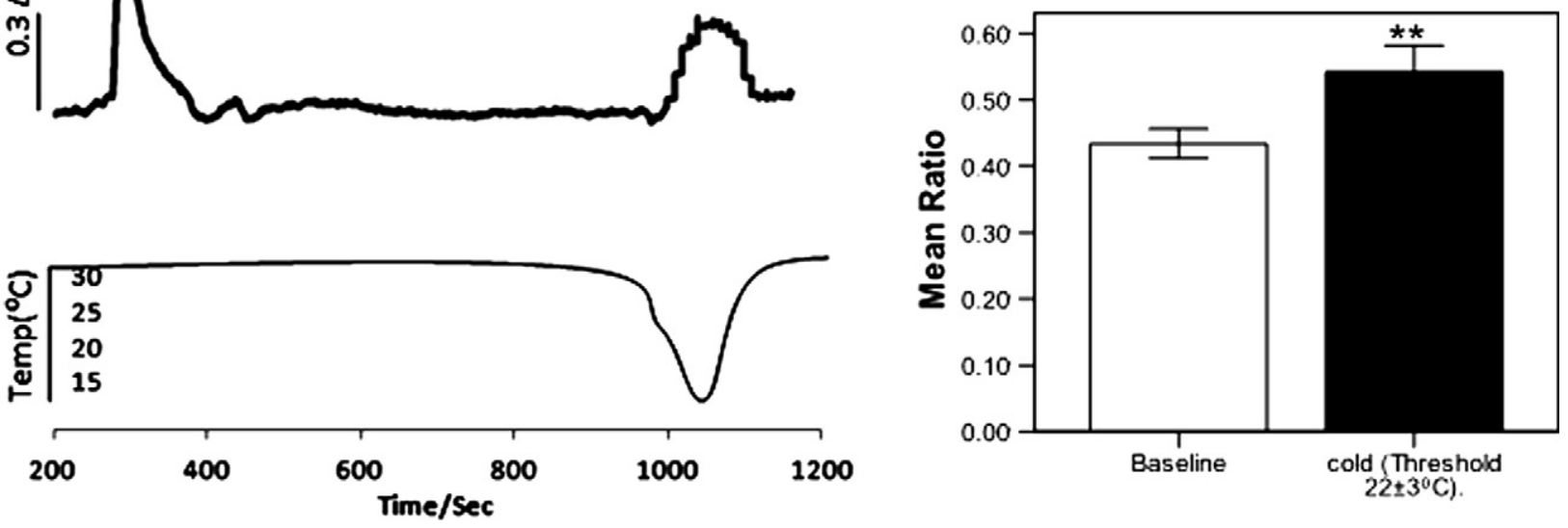

(C) Menthol
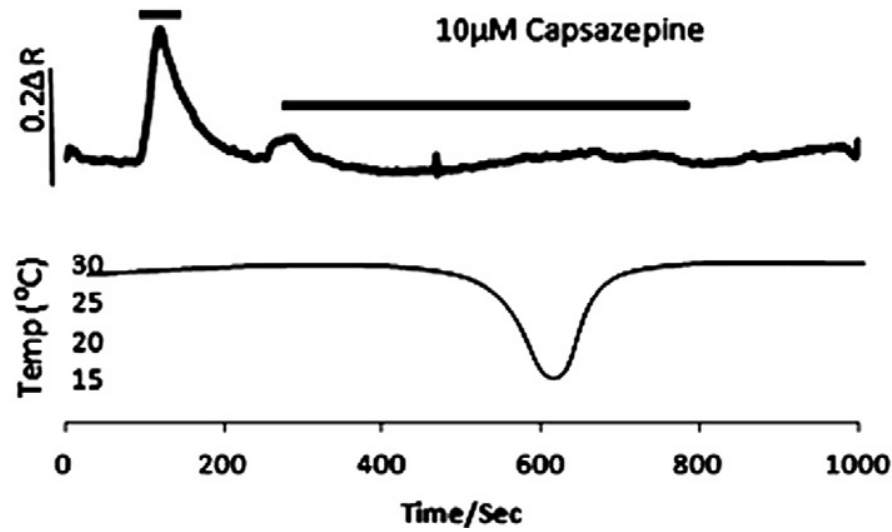

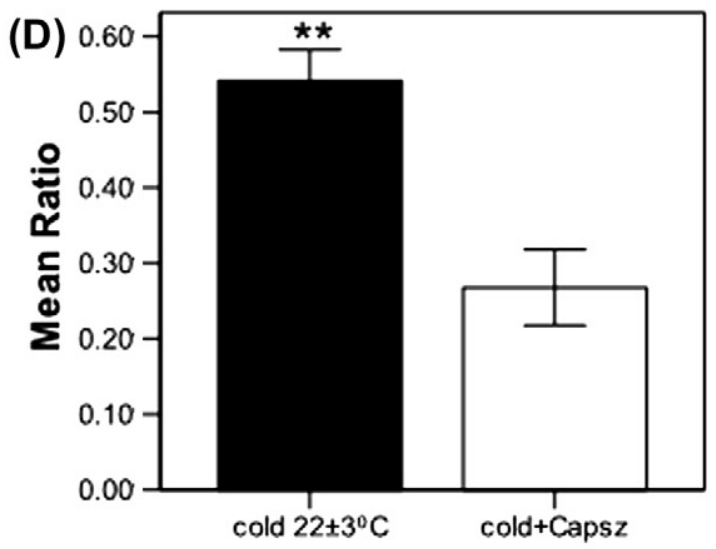

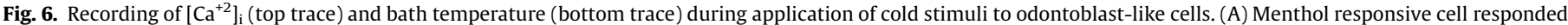

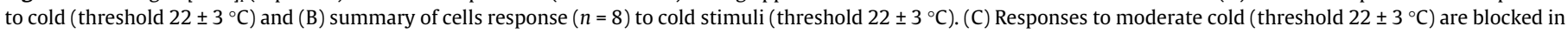

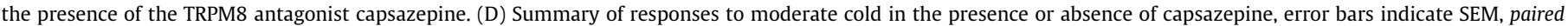
Student $t$ test ${ }^{* *} p \leqslant 0.01$, unpaired Student t test ${ }^{* *} p \leqslant 0.01$.

\subsubsection{Thermal stimuli induce changes in $\left[\mathrm{Ca}^{2+}\right]_{i}$}

To examine the effect of thermal stimuli on odontoblasts, the temperature in the recording chamber was altered. Increasing the temperature from 36 to $46{ }^{\circ} \mathrm{C}$ evoked a substantial increase in $\left[\mathrm{Ca}^{2+}\right]_{i}$ in capsaicin responsive cells which was evident at $43 \pm 2{ }^{\circ} \mathrm{C}(p=0.002, n=10$, Fig. $5 \mathrm{~A}$ and $\mathrm{B})$. The response to heat in capsaicin sensitive cells was consistently blocked in the presence of the TRPV1 antagonist capsazepine ( $p=0.03$, Fig. $5 C$ and D).

Reducing the bath temperature also resulted in an increase in $\left[\mathrm{Ca}^{2+}\right]_{\mathrm{i}}$, and to investigate odontoblast responses to cold stimuli we exposed the cells to two different cold thresholds. In a set of experiments cells were exposed to moderately cold stimuli by lowering the bath temperature from 30 to $15^{\circ} \mathrm{C}$. In these experiments cells responded by increase in $\left[\mathrm{Ca}^{2+}\right]_{i}$, when the temperature in the recording chamber was in the range of $22 \pm 3^{\circ} \mathrm{C}$. To test whether these cold responses were mediated via TRPM8, cells were first stimulated with menthol and the menthol responsive cells were exposed to moderate cold $22 \pm 3^{\circ} \mathrm{C}$. As shown in Fig. $6 \mathrm{~A}$ and $\mathrm{B}$ these cells responded by significant increase in $\left[\mathrm{Ca}^{2+}\right]_{i},(p=0.002$, $n=8$ ). In addition these responses to moderate cold were abolished when the cells were incubated with capsazepine prior to cold stimulation (Fig. 6C and D, $p=0.01$ ).

In another set of experiments odontoblasts were exposed to noxious cold by lowering the bath temperature from 20 to $10{ }^{\circ} \mathrm{C}$ and at this temperature the cells responded by significant increase in $\left[\mathrm{Ca}^{2+}\right]_{i}$. As detailed above for TRPM8, the response of cells to the TRPA1 agonist, cinnamaldehyde, was first tested prior to exposure to noxious cold. The majority of cinnamaldehyde and icilin responsive cells responded to cold stimulation when the temperature in the recording chamber was in the range of $12 \pm 2{ }^{\circ} \mathrm{C}(p=0.001, n=23$, Fig. $7 \mathrm{~A}$ and $\mathrm{B}$, and data not shown). Furthermore the response of icilin and cinnamaldehyde sensitive cells to cold $\left(12 \pm 2^{\circ} \mathrm{C}\right)$ was attenuated in the presence of the selective TRPA1 antagonist HC-030031 ( $p=0.03$, Fig. 7C and D), and RuR (data not shown).

\subsection{TRPA1 SIRNA}

To further study the role of TRPA1 in mediating cold responses in odontoblasts we performed a gene silencing approach using TRPA1 siRNA. Treatment of odontoblasts with 50nM TRPA1 siRNA resulted in a significant reduction in TRPA1 protein expression as shown by western blotting ( $p=0.001$, Fig. 7E). When transfected cells were assayed for functionality there was a reduction in the magnitude of the responses to cinnamaldehyde and cold threshold $\left(12 \pm 2{ }^{\circ} \mathrm{C}\right)$ compared to control cells transfected with scrambled siRNA $(p=0.04, n=12$, Fig. $7 F$ and $G)$. The viability of the transfected cells after cold stimulus application was evaluated by application of $1 \mu \mathrm{M}$ ionomycin and transfected cells showed a robust increase in $\left[\mathrm{Ca}^{2+}\right]_{\mathrm{i}}$, (mean $0.5 \Delta R$ ). 
(A)

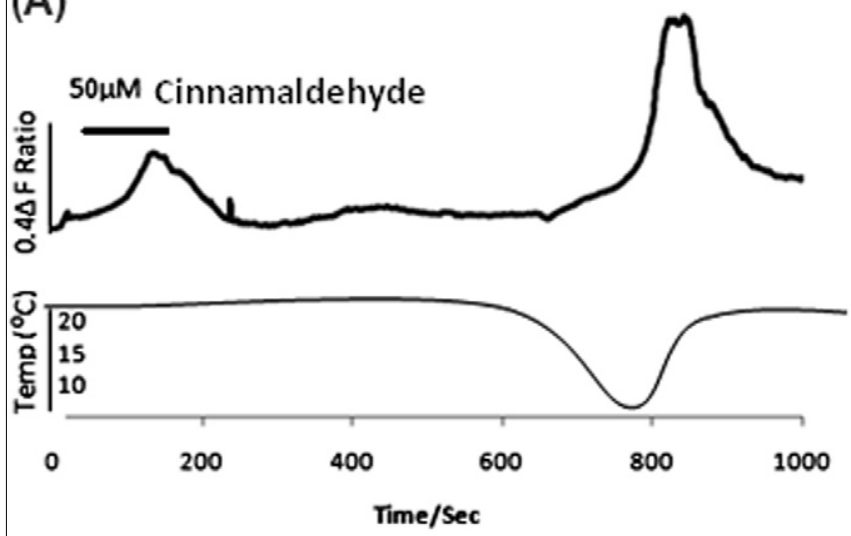

(C)

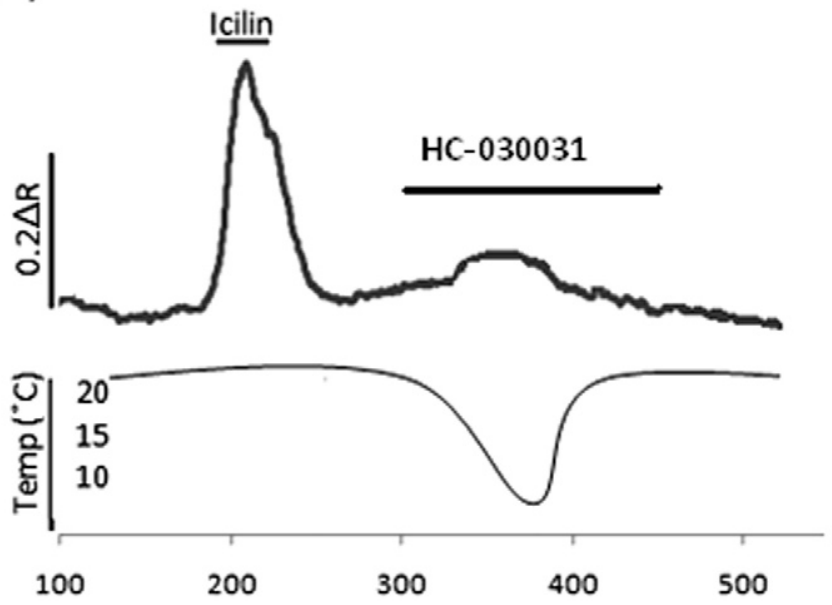

(B)

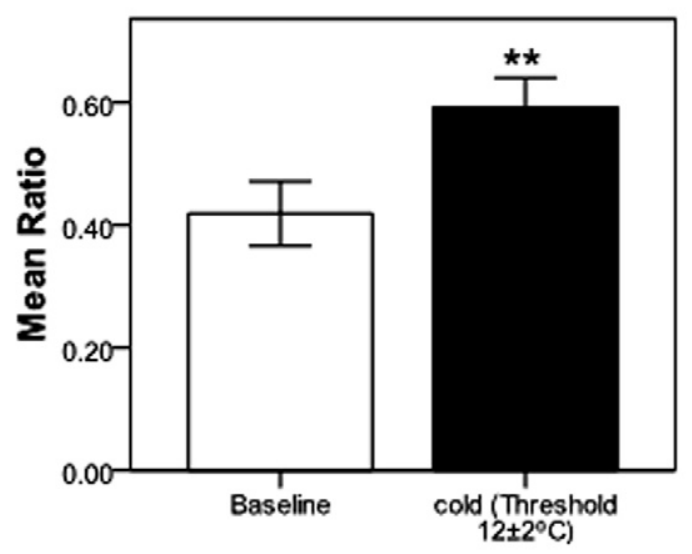

(D)

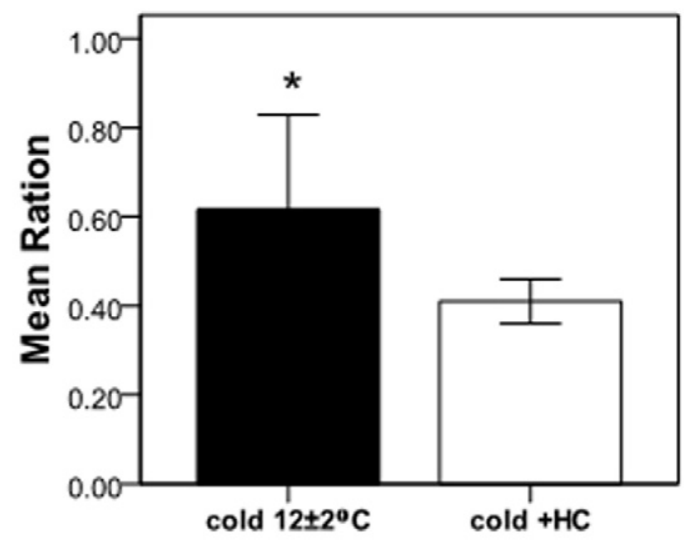

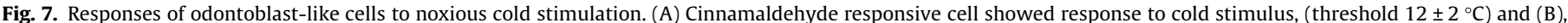

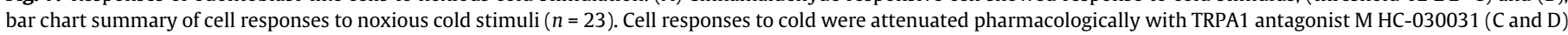

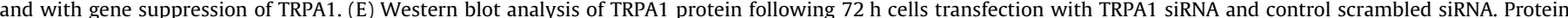

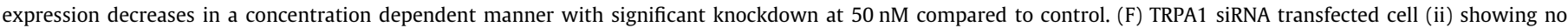

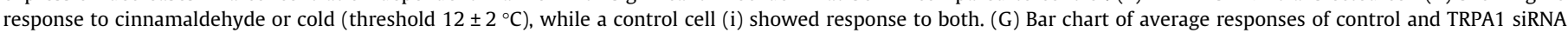
transfected cells to cold $(n=12)$ (threshold $12 \pm 2{ }^{\circ} \mathrm{C}$ ), error bars indicate SEM, paired Student $t$ test ${ }^{* *} p \leqslant 0.01,{ }^{*} p \leqslant 0.05$.

\subsubsection{TRP ligands induce changes in $\left[\mathrm{Ca}^{2+}\right]_{i}$ in native odontoblasts ex vivo}

In addition to cultured odontoblasts we also examined the ex-vivo functional expression of thermo-sensitive TRP channels in native odontoblasts using dental pulp slices preparations obtained from freshly extracted healthy molar teeth. Using fura2-AM we found that the TRP agonists cinnamaldehyde, menthol and capsaicin induced increases in $\left[\mathrm{Ca}^{2+}\right]_{i}$ similar to those observed in cultured odontoblasts (Figs. 8A and B).

\section{Discussion}

The present report demonstrates for the first time that human odontoblasts express functional thermo-sensitive TRP channels, TRPA1, TRPV1 and TRPM8. Using PCR and western blotting we demonstrated gene and protein expression of these channels and our immunohistochemical results confirmed their cellular localisation as has previously been described for non neuronal TRP channels $[28,9]$. The cultured odontoblast-like cells used in this study were derived from pulp tissue explants using a previously validated method $[1,4]$. The odontoblastic phenotype of the cells was confirmed using gene expression of the odontogenic markers DSPP and nestin [2]. To further confirm localisation of TRP channels to human odontoblasts we performed double staining immunohistochemistry with antibody to the odontoblast marker dentin sialoprotein (DSP) and showed co-localisation of TRPA1, TRPV1 and TRPM8 with DSP positive cells. In addition to well-defined expression by odontoblasts, DSP has also been shown to be very minimally expressed by osteoblasts [42]. However, osteoblasts are not part of the cellular population in the dental pulp and therefore do not confound interpretation of our double staining with DSP as a demonstration of TRP channels co-localisation with cells of an odontoblastic phenotype.

We have also demonstrated by immunohistochemistry ex-vivo expression of TRPA1, TRPV1 and TRPM8 in native odontoblasts in dental pulp of healthy third molars. These results provide conclusive evidence for gene and protein expression of thermo-sensitive TRP channels in human odontoblasts.

In addition to odontoblasts, our immunohistochemical studies revealed expression of TRP channels in some of the cells of the dental pulp ex-vivo. The dental pulp is populated by different cell types including fibroblasts, undifferentiated mesenchymal cells and defence cells. The undifferentiated mesenchymal cells can differenti- 
(E)

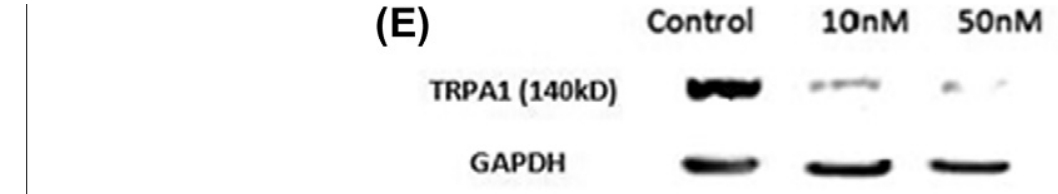

(F)
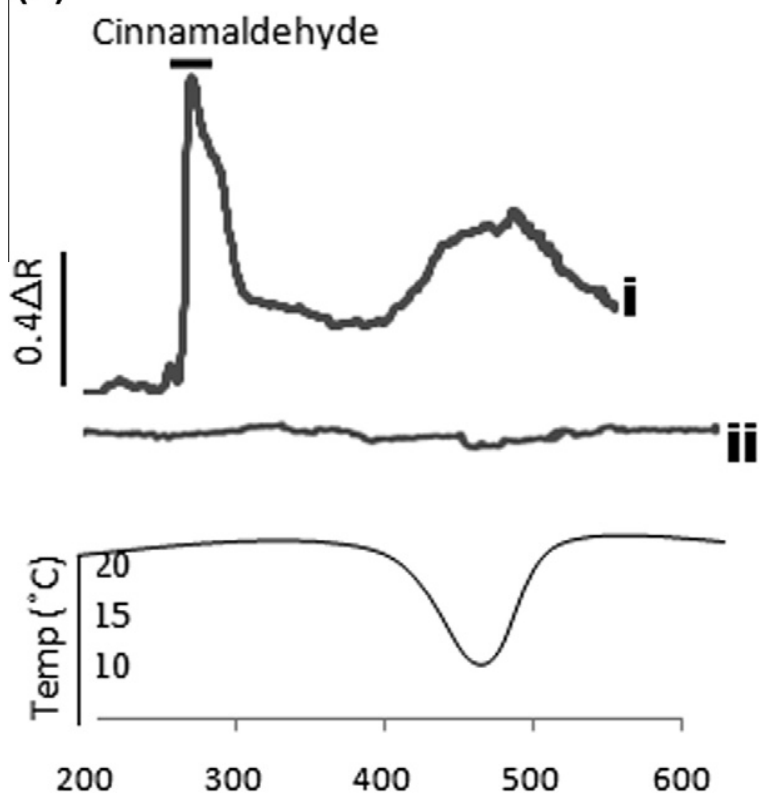

(G)

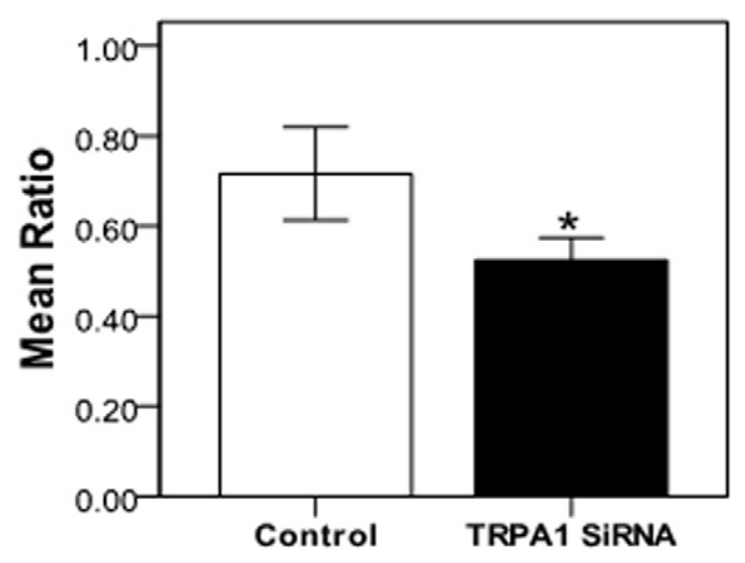

Fig. 7 (continued)

ate into odontoblasts following injury and damage to odontoblasts. It is tempting to speculate that expression of TRP channels in pulp cells is likely to be conserved in the undifferentiated mesenchymal cells. Previous work on ion channels in undifferentiated dental pulp cells showed expression of sodium and potassium channels $[15,16]$, which was later confirmed in differentiated odontoblasts $[3,4]$.

TRP channels respond to stimuli by activation of calcium fluxes. We therefore used ratiometric calcium imaging to test the functionality of these channels. Ratiometric calcium imaging was performed to record changes in $\left[\mathrm{Ca}^{2+}\right]_{i}$ in response to TRP chemical agonists and thermal stimuli. We have demonstrated that odontoblasts, whether they are cultured or native cells within the dental pulp, can be stimulated by TRP ligands.

Odontoblasts showed responses to capsaicin which was abolished in the presence of capsazepine indicating functional expression of TRPV1. TRPV1 is a capsaicin gated ion channel that responds to heat $\left(>43^{\circ} \mathrm{C}\right)$ [12] and has been shown to play an essential role in inflammatory thermal hyperalgesia [17]. Previous work reported the expression of TRPV1 in undifferentiated dental pulp cells, and although its functionality was not investigated via change in $\left[\mathrm{Ca}^{2+}\right]_{\mathrm{i}}$, it was shown that capsaicin induced IL-6 production in dental pulp cells via activation of TRPV1 [35]. In the present report we demonstrated for the first time that in addition to activation by capsaicin, TRPV1 channels in human odontoblasts can also be activated by noxious heat, indicating a potential role in thermal transduction in human teeth and mediation of thermal hyperalgesia associated with pulpal inflammation. It is well known that TRPV1 is sensitised by several inflammatory mediators [53] and since dentin sensitivity has been reported to increase during pulp inflammation [36] it is tempting to speculate that thermal hyperalgesia associated with pulp inflammation could be mediated via TRPV1.
As well as TRPV1, odontoblasts also express functional TRPA1 and TRPM8, as indicated by their response to icilin, menthol and cinnamaldehyde. Icilin and menthol induced different responses in odontoblastic cells. Icilin responses were blocked by RuR in most but not all of the cells. Menthol produced a highly efficacious response that was blocked in the presence of capsazepine but persisted in the presence of RuR indicating expression of TRPM8 as previously described [41]. However, in some other cells the response was not blocked by capsazepine and since menthol is also known to activate TRPA 125,50$]$, it is possible that these menthol responses were mediated via TRPA1. Activation of many of the cells by the TRPA1 and TRPM 8 agonists cinnamaldehyde, menthol and icilin and the demonstration of their expression and cellular localisation in human odontoblasts by western blotting and immunohistochemistry provides strong evidence that human odontoblasts express functional TRPA1 and TRPM8. In recent reports expression of TRPM8 and TRPA1 was not demonstrated in mouse and rat odontoblasts $[45,52]$. However, since species differences in TRP channel expression and function have previously been observed [29,13], this difference in TRPA1 and TRPM8 expression between mouse/rat and human odontoblasts may simply reflect different physiological relevance in different species.

Odontoblasts also produced variable responses to cold stimulation. In line with previous evidence for cold induced responses in neuronal and non neuronal TRPM8 expressing cells $[41,28]$, we showed that some of the menthol sensitive odontoblasts responded to reducing temperature $\left(22 \pm 3^{\circ} \mathrm{C}\right)$ by an increase in $\left[\mathrm{Ca}^{2+}\right]_{\mathrm{i}}$ indicating that odontoblasts may sense cold via TRPM8. This TRPM8 mediated cold response was further confirmed by attenuation of the response by capsazepine in agreement with previous reports $[41,28]$. Odontoblasts also responded to noxious cold at a threshold of $12 \pm 2{ }^{\circ} \mathrm{C}$. This response was attenuated in the presence of the TRPA1 selective antagonist HC-030031. TRPA1 has been 
(A)
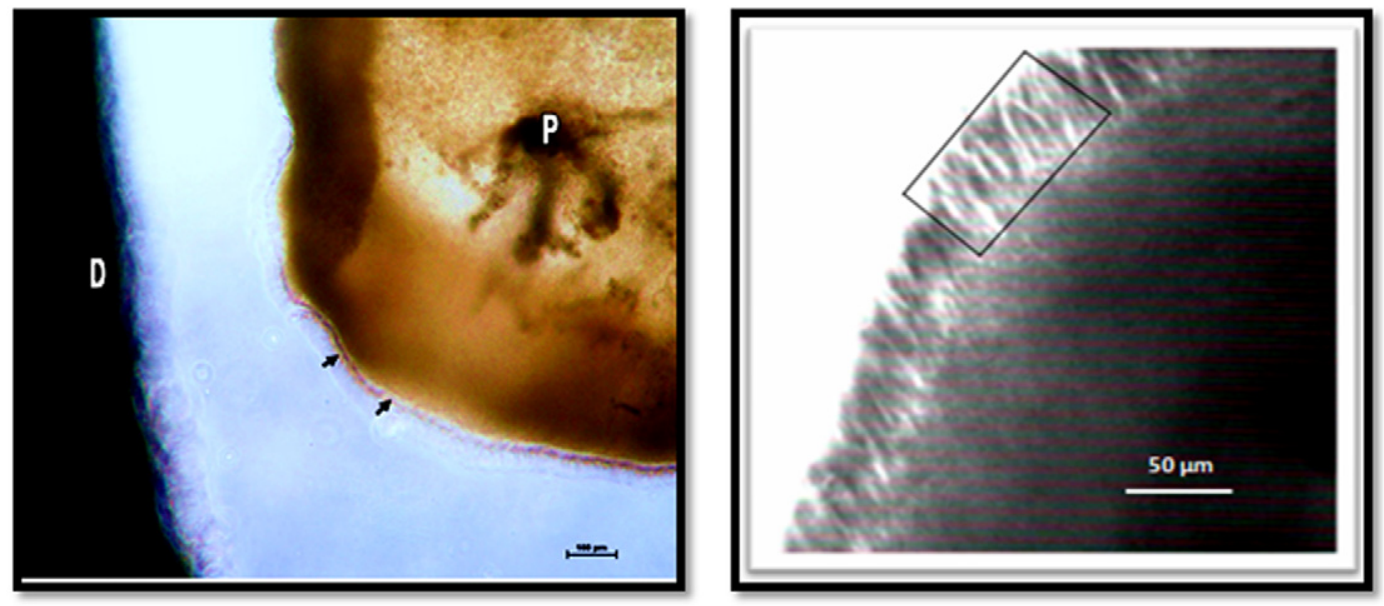

(B)
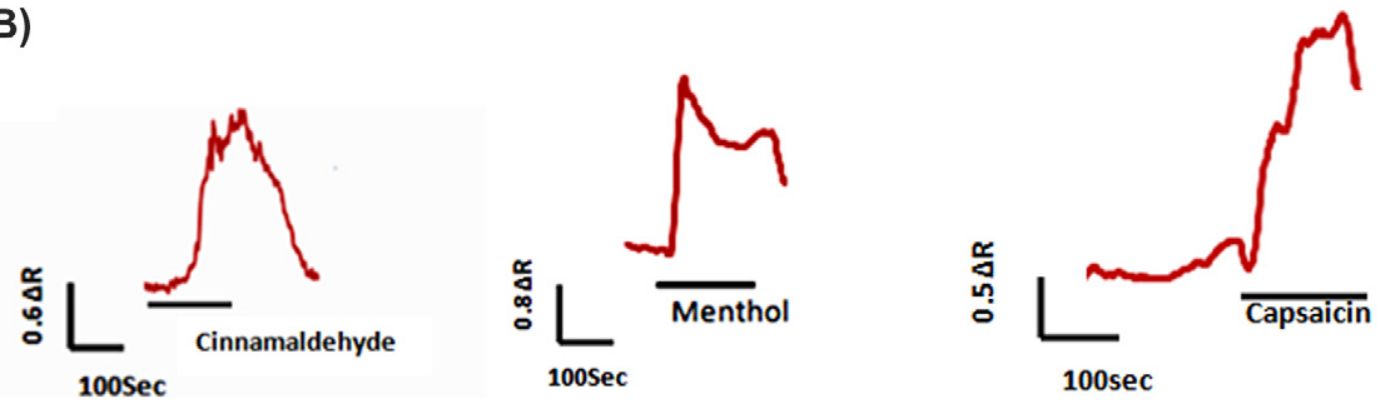

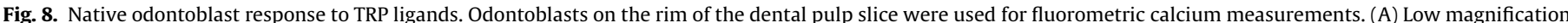

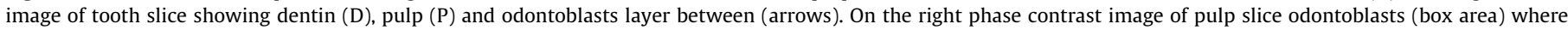

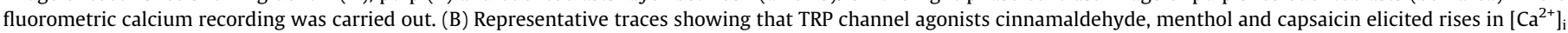
in native odontoblasts.

proposed to be activated by temperatures that are perceived as noxiously cold $[47,7]$, however this mode of activation remains controversial $[23,8,19,24]$. To further explore the role of TRPA1 in cold responses in odontoblasts we performed siRNA knockdown of TRPA1. We demonstrated a reduction in responses to the specific TRPA1 agonist cinnamaldehyde and cold responses at a threshold of $12 \pm 2{ }^{\circ} \mathrm{C}$, suggesting a role for TRPA 1 in mediating noxious cold sensation in line with previous reports $[47,7,19,24]$.

Our findings clearly demonstrate a potential role for TRPM8 and TRPA1 in transduction of cold responses in human odontoblasts; however, the contributions of other cold transduction molecules cannot be ruled out. In addition to TRPM8 and TRPA1 several other potassium and sodium channels have been implicated in cold transduction $[43,49]$. Whether these ion channels play a role in cold transduction in odontoblasts has yet to be elucidated and thus the present report is the first to describe a molecular mechanism for cold transduction in human odontoblasts.

Previous reports have shown that odontoblasts are excitable cells that can generate action potentials [4] and our current findings demonstrate that odontoblasts can sense environmental stimuli through expression of TRP Channels. However, it is not yet clear how odontoblasts signal to and communicate with nociceptive afferent terminals in the dental pulp, and both electrical and paracrine paths of communication have been suggested. Odontoblasts lie in close proximity to afferent terminals, but in the absence of gap junctions between odontoblasts and nerves it has been suggested that communication between odontoblasts and nerves could be an ephaptic transmission, in which electric fields generated by odontoblasts may alter the excitability of neighbouring neurons [4]. Alternatively the release of intercellular signalling molecules such as ATP from odontoblasts is a poten- tial mechanism of paracrine communication that merits further investigation.

Functional expression of thermo-sensitive TRP channels in human odontoblasts may indicate a crucial role for these cells not only in transduction of thermal stimuli in human teeth but also in mediating pain and inflammation. Tooth pain is generally induced by thermal changes in the oral cavity and the peripheral location of odontoblasts as the outermost cell layer of the dental pulp make them suitable candidates to sense external stimuli in a manner similar to that reported in skin keratinocytes. The expression of thermo-sensitive TRP channels has been reported in keratinocytes to mediate not only thermo-sensation [30], but also other functions that might be important for neuronal responses. It has been suggested that TRP channels in non-neural tissues could act in concert with neurons to mediate pain and inflammation. Indeed activation of thermo-sensitive TRP channels was shown to induce release of inflammatory cytokines $[35,44,6]$ that may promote inflammation directly or sensitise the sensory neurons to augment neurogenic inflammation and nociceptive signalling [46].

TRPV1 and TRPA1 co-localise with peptidergic sensory neurons expressing substance $\mathrm{P}$ and calcitonin gene related peptide. Pungent irritants such as capsaicin and mustard oil induce neurogenic inflammation through their respective receptors TRPV1 and TRPA1 $[48,5]$. The role of neuropeptides in pulpal pain and inflammation has previously been described [31] and recently pulpal fibroblasts and odontoblasts have been shown to express neuropeptides $[26,38]$. The possibility that TRPA1 and TRPV1 channels in dental pulp cells could play a role in the release of neuropeptides and thus contribute to the development of neurogenic inflammation merits further investigation. 
In summary, we provide the first evidence that human odontoblasts express functional thermo-sensitive TRP channels suggesting that these cells might act in concert with sensory neurons to perceive thermal stimuli and to activate adaptive responses to environmental stressors.

\section{Conflict of interest statement}

The authors declare no conflicts of interest.

\section{Acknowledgement}

Authors would like to thank Ms. Catherine Fulton and the staff in the Tissue Core Facility QUB for technical assistance, Professor Alex Zholos QUB, for providing TRPM8 antibody, Dr. John Marley QUB for facilitating collection of extracted teeth, Dr. Cheryl McFarlane QUB for assistance with confocal imaging and Dr. George McKerr, University of Ulster for assistance with immunohistochemistry imaging.

This work was supported by Research Grants from the Royal College of Surgeons of Edinburgh and the British Endodontic Society.

\section{References}

[1] About I, Bottero MJ, de Denato P, Camps J, Franquin JC, Mitsiadis TA. Human dentin production in vitro. Exp Cell Res 2000;258:33-41.

[2] About I, Laurent-Maquin D, Lendahl U, Mitsiadis TA. Nestin expression in embryonic and adult human teeth under normal and pathological conditions. Am J Pathol 2000;157:287-95.

[3] Allard B, Couble ML, Magloire H, Bleicher F. Characterization and gene expression of high conductance calcium-activated potassium channels displaying mechanosensitivity in human odontoblasts. J Biol Chem 2000;275:25556-61.

[4] Allard B, Magloire H, Couble ML, Maurin JC, Bleicher F. Voltage-gated sodium channels confer excitability to human odontoblasts: possible role in tooth pain transmission. J Biol Chem 2006;281:29002-10.

[5] Andre E, Campi B, Materazzi S, Trevisani M, Amadesi S, Massi D, Creminon C, Vaksman N, Nassini R, Civelli M, Baraldi PG, Poole DP, Bunnett NW, Geppetti P, Patacchini R. Cigarette smoke-induced neurogenic inflammation is mediated by alpha, beta-unsaturated aldehydes and the TRPA1 receptor in rodents. J Clin Invest 2008;118:2574-82.

[6] Atoyan R, Shander D, Botchkareva NV. Non-neuronal expression of transient receptor potential type A1 (TRPA1) in human skin. J Invest Dermatol 2009;129:2312-5.

[7] Bandell M, Story GM, Hwang SW, Viswanath V, Eid SR, Petrus MJ, Earley TJ, Patapoutian A. Noxious cold ion channel TRPA1 is activated by pungent compounds and bradykinin. Neuron 2004;41:849-57.

[8] Bautista DM, Jordt SE, Nikai T, Tsuruda PR, Read AJ, Poblete J, Yamoah EN, Basbaum AI, Julius D. TRPA1 mediates the inflammatory actions of environmental irritants and proalgesic agents. Cell 2006;124:1269-82.

[9] Bidaux G, Roudbaraki M, Merle C, Crepin A, Delcourt P, Slomianny C, Thebault S, Bonnal JL, Benahmed M, Cabon F, Mauroy B, Prevarskaya N. Evidence for specific TRPM8 expression in human prostate secretory epithelial cells: functional androgen receptor requirement. Endocr Relat Cancer 2005;12: 367-82.

[10] Brännström M, Lindén LA, Aström A. The hydrodynamics of the dental tubule and of pulp fluid. A discussion of its significance in relation to dentinal sensitivity. Caries Res 1967;1:310-7.

[11] Byers MR. Dental sensory receptors. Int Rev Neurobiol 1984;25:39-94.

[12] Caterina MJ, Schumacher MA, Tominaga M, Rosen TA, Levine JD, Julius D. The capsaicin receptor: a heat-activated ion channel in the pain pathway. Nature 1997;389:816-24.

[13] Chen J, Kym PR. TRPA1: the species difference. J Gen Physiol 2009;133:623-5.

[14] Chidchuangchai W, Vongsavan N, Matthews B. Sensory transduction mechanisms responsible for pain caused by cold stimulation of dentine in man. Arch Oral Biol 2007;52:154-60.

[15] Davidson RM. Potassium currents in cells derived from human dental pulp. Arch Oral Biol 1993;38:803-11.

[16] Davidson RM. Neural form of voltage-dependent sodium current in human cultured dental pulp cells. Arch Oral Biol 1994;39:613-20.
[17] Davis JB, Gray J, Gunthorpe MJ, Hatcher JP, Davey PT, Overend P, Harries MH, Latcham J, Clapham C, Atkinson K, Hughes SA, Rance K, Grau E, Harper AJ, Pugh PL, Rogers DC, Bingham S, Randall A, Sheardown SA. Vanilloid receptor-1 is essential for inflammatory thermal hyperalgesia. Nature 2000;405:183-7.

[18] Doerner JF, Gisselmann G, Hatt H, Wetzel CH. Transient receptor potentialchannel $\mathrm{A} 1$ is directly gated by calcium ions. J Biol Chem 2007;282:13180-9.

[19] Fajardo O, Meseguer V, Belmonte C, Viana F. TRPA1 channels mediate cold temperature sensing in mammalian vagal sensory neurons: pharmacological and genetic evidence. J Neurosci 2008;28:7863-75.

[20] Fischer C, Fischer RG, Wennberg A. Prevalence and distribution of cervical dentinhypersensitivity in a population in Rio de Janeiro, Brazil. J Dent 1992;20:272-6.

[21] Grynkiewicz G, Poenie M, Tsien RY. A new generation of $\mathrm{Ca}^{2+}$ indicators with greatly improved fluorescence properties. J Biol Chem 1985;260:3440-50.

[22] Holland GR, Narhi MN, Addy M, Gangarosa L, Orchardson R. Guidelines for the design and conduct of clinical trials on dentine hypersensitivity. J Clin Periodontol 1997;24:808-13.

[23] Jordt SE, Bautista DM, Chuang HH, McKemy DD, Zygmunt PM, Hogestatt ED, Meng ID, Julius D. Mustard oils and cannabinoids excite sensory nerve fibres through the TRP channel ANKTM1. Nature 2004;427:260-5.

[24] Karashima Y, Talavera K, Everaerts W, Janssens A, Kwan KY, Vennekens R Nilius B, Voets T. TRPA 1 acts as a cold sensor in vitro and in vivo. Proc Natl Acad Sci USA 2009;106:1273-8.

[25] Karashima Y, Damann N, Prenen J, Talavera K, Segal A, Voets T, Nilius B. Bimodal action of menthol on the transient receptor potential channel TRPA1.J Neurosci 2007;27:9874-84.

[26] Killough SA, Lundy FT, Irwin CR. Substance P expression by human dental pulp fibroblasts: a potential role in neurogenic inflammation. J Endod 2009;35:73-7.

[27] Kim S. Thermal stimuli in dentinal sensitivity. Endod Dent Traumatol 1986;2:138-40.

[28] Kochukov MY, McNearney TA, Fu Y, Westlund KN. Thermosensitive TRP ion channels mediate cytosolic calcium response in human synoviocytes. Am J Physiol Cell Physiol 2006;291:C424-32.

[29] Lee N, Chen J, Sun L, Wu S, Gray KR, Rich A, Huang M, Lin JH, Feder JN, Janovitz EB, Levesque PC, Blanar MA. Expression and characterization of human transient receptor potential melastatin 3 (hTRPM3). J Biol Chem 2003;278:20890-7.

[30] Lumpkin EA, Caterina MJ. Mechanisms of sensory transduction in the skin. Nature 2007;445:858-65.

[31] Lundy FT, Linden GJ. Neuropeptides and neurogenic mechanisms in oral and periodontal inflammation. Crit Rev Oral Biol Med 2004;15:82-98.

[32] Magloire H, Couble ML, Thivichon-Prince B, Maurin JC, Bleicher F. Odontoblast: a mechano-sensory cell. J Exp Zool B Mol Dev Evol 2008;312B:416-24.

[33] Magloire H, Lesage F, Couble ML, Lazdunski M, Bleicher F. Expression and localization of TREK-1 $\mathrm{K}^{+}$channels in human odontoblasts. J Dent Res 2003;82:542-5.

[34] Maurin JC, Couble ML, Didier-Bazes M, Brisson C, Magloire H, Bleicher F. Expression and localization of reelin in human odontoblasts. Matrix Biol 2004;23:277-85.

[35] Miyamoto R, Tokuda M, Sakuta T, Nagaoka S, Torii M. Expression and characterization of vanilloid receptor subtype 1 in human dental pulp cell cultures. J Endod 2005;31:652-8.

[36] Närhi M, Yamamoto H, Ngassapa D, Hirvonen T. The neurophysiological basis and the role of inflammatory reactions in dentine hypersensitivity. Arch Oral Biol 1994;39:23S-30S.

[37] Okumura R, Shima K, Muramatsu T, Nakagawa K, Shimono M, Suzuki T, Magloire H, Shibukawa Y. The odontoblast as a sensory receptor cell? The expression of TRPV1 (VR-1) channels. Arch Histol Cytol 2005;68:251-7.

[38] Paakkonen V, Bleicher F, Carrouel F, Vuoristo JT, Salo T, Wappler I, Couble ML, Magloire H, Peters H, Tjaderhane L. General expression profiles of human native odontoblasts and pulp-derived cultured odontoblast-like cells are similar but reveal differential neuropeptide expression levels. Arch Oral Biol 2009;54:55-62.

[39] Park CK, Kim MS, Fang Z, Li HY, Jung SJ, Choi SY, Lee SJ, Park K, Kim JS, Oh SB. Functional expression of thermo-transient receptor potential channels in dental primary afferent neurons: implication for tooth pain. J Biol Chem 2006;281:17304-11.

[40] Pashley DH. Dynamics of the pulpo-dentin complex. Crit Rev Oral Biol Med 1996; 7:104-33.

[41] Peier AM, Moqrich A, Hergarden AC, Reeve AJ, Andersson DA, Story GM, Earley TJ, Dragoni I, McIntyre P, Bevan S, Patapoutian A. A TRP channel that senses cold stimuli and menthol. Cell 2002;108:705-15.

[42] Qin C, Brunn JC, Cadena E, Ridall A, Butler WT. Dentin sialoprotein in bone and dentin sialophosphoprotein gene expressed by osteoblasts. Connect Tissue Res 2003;44:179-83.

[43] Reid G, Flonta M. Cold transduction by inhibition of a background potassium conductance in rat primary sensory neurones. Neurosci Lett 2001;297:171-4.

[44] Sabnis AS, Reilly CA, Veranth JM, Yost GS. Increased transcription of cytokine genes in human lung epithelial cells through activation of a TRPM8 variant by cold temperatures. Am J Physiol Lung Cell Mol Physiol 2008;295:L194-200.

[45] Son AR, Yang YM, Hong JH, Lee SI, Shibukawa Y, Shin DM. Odontoblast TRP channels and thermo/mechanical transmission. J Dent Res 2009;88:1014-9. 
[46] Southall MD, Vasko MR. Prostaglandin receptor subtypes, EP3C and EP4 mediate the prostaglandin E2-induced cAMP production and sensitization of sensory neurons. J Biol Chem 2001;276:16083-91.

[47] Story GM, Peier AM, Reeve AJ, Eid SR, Mosbacher J, Hricik TR, Earley TJ, Hergarden AC, Andersson DA, Hwang SW, McIntyre P, Jegla T, Bevan S, Patapoutian A. ANKTM1, a TRP-like channel expressed in nociceptive neurons, is activated by cold temperatures. Cell 2003;112:819-29.

[48] Szallasi A, Blumberg PM. Vanilloid (capsaicin) receptors and mechanisms. Pharmacol Rev 1999;51:159-212.

[49] Viana F, de la Pena E, Belmonte C. Specificity of cold thermotransduction is determined by differential ionic channel expression. Nat Neurosci 2002;5:254-60
[50] Xiao B, Dubin AE, Bursulaya B, Viswanath V, Jegla TJ, Patapoutian A. Identification of transmembrane domain 5 as a critical molecular determinant of menthol sensitivity in mammalian TRPA1 channels. J Neurosci 2008;28:9640-51.

[51] Xing H, Chen M, Ling J, Tan W, Gu JG. TRPM8 mechanism of cold allodynia after chronic nerve injury. J Neurosci. 2007;27:13680-90.

[52] Yeon KY, Chung G, Shin MS, Jung SJ, Kim JS, Oh SB. Adult rat odontoblasts lack noxious thermal sensitivity. J Dent Res 2009;88:328-32.

[53] Zhang X, Li L, McNaughton PA. Proinflammatory mediators modulate the heatactivated ion channel TRPV1 via the scaffolding protein AKAP79/150. Neuron 2008;59:450-61. 